\title{
Research on the Performance of FDI Policies in Real Estate Industry
}

\author{
Siyu Tong \\ Wuhan University of Technology \\ Wuhan, China \\ tongsiyu0@outlook.com
}

\begin{abstract}
In order to improve the effectiveness of the real estate policy and promote the healthy development of the industry, this paper takes the real estate FDI industry policy from 2006 to 2015 as the research object and builds the real estate FDI policy measurement system. And based on this, the quantitative value and the selected economic indicators were analyzed. The analysis shows that the FDI policy of China's real estate industry has a positive effect on the healthy development of the industry as a whole, but the driving force of policy implementation is lacking, and we need to strengthen policy efforts.
\end{abstract}

Keywords-the real estate; FDI; policy performance; measurement of policy

\section{INTRODUCTION}

In China, real estate occupies an important position in the development of economic; it is interlinked with other industries and leads to the development of other industries. It is one of the pillar industries of our national economy. Foreign Direct Investment (FDI) is the main way for foreign investment in China's real estate market. FDI has stimulated the development and improvement of China's real estate enterprises. However, the unreasonable introduction and use of FDI may lead to the bubble economy and affect the domestic real estate industry as well as regional economic security. Due to the existence of market failure, the government must make use of the policy as a tool to make up for the lack of market. However, the policy may not be able effectively promote the development of the industry because of its subjectivity and uncertainty. Therefore, discussing the performance of the real estate industry FDI policy is of great significance to the healthy development of the real estate industry.

For the research of policy of real estate FDI, the current scholars have already analyzed the potency and timing (S Malpezzi, 2001)[1], the effectiveness (Lv Ying,2007)[2], the content analysis of the policy(Li Rui, 2011)[3] and so on, giving guidance to the formulation of government's future policies. Most of the studies on the effectiveness of policy adopt the qualitative method. Although this method is low in cost and easy to operate, it is hard to rule out the subjective factors in expert evaluation. To solve this problem, more and more scholars try to use the method of quantification to analyze the policy. The United States economists Gary D. Rebecca(1978)[4], Qian Wei, Lu Kewei(2007)[5], Liu Fengchao and Sun Yutao(2007)[6], Yin Huafang(2006)[7] and $\mathrm{Xu}$ HongYi(2014)[8] quantified the mineral rights of Huada
Related activities, science and technology related texts, innovation policy, "Guiding Catalog of Foreign Investment Industries”, and financial policy. Peng Jisheng and Zhong Weiguo(2008) divided the policy into three dimensions: policy potency, policy measures and policy goals, and established the policy measurement system, and get the annual performance of the innovation policy through data processing[9]. This paper will draw lessons from this method to discuss the performance of the real estate FDI industry policy.

\section{MEASUREMENT OF POLICY}

\section{A. Sample Source of Policies}

According to the relevant index of real estate FDI in China Statistical Yearbook, the policy of real estate FDI is defined as: policies on regulating the qualifications and flows of FDI in real estate industry. This paper only includes the policies promulgated at the central level by State Council of China and so on. Based on the above standard, we screened out 98 FDI policies of real estate to build real estate FDI policies database. Those policies are independently released or co-published by agencies such as the Ministry of Commerce, the State Administration of Taxation, the Ministry of Finance, the State Administration of Foreign Exchange, the Ministry of Land and Resources, the Ministry of Housing and Urban-Rural Development and the NDRC.

\section{B. Establish Quantitative Standards}

With reference to the research results of Peng Jisheng et al., this paper quantifies the policies of real estate FDI from the three dimensions of policy potency, policy measures, and policy goals. Policy potency is an index of the legal effects of policies. By analyzing the levels of institutions which promulgated the policies and types of policies in real estate industry, we assigned values of $5,4,3,2$ and 1 for different standards of policies. Generally speaking, when the level of the institution promulgated arise, the effectiveness of the policy increase subsequently. Therefore, the higher the quantile value of the policy. However, since such policies are usually macrolevel, it is difficult to formulate the implementing agencies detailed implementation of standards. So in the policy measures and policy goals dimensions, the quantile value is small. The lower-level policies are generally more specific in terms of policy implementation. Therefore, the dimensions of policy goals and measures can achieve higher quantitative scores. Combination of both can truly reflect the performance 
of the policies to make up for the shortcomings of a single index. The quantification standard of real estate FDI policy is shown in Table I.

TABLE I. QUANTITATIVE STANDARD OF FDI POLICY IN REAL ESTATE INDUSTRY

\begin{tabular}{|c|c|}
\hline $\begin{array}{l}\text { Policy potency } \\
\text { score }\end{array}$ & Quantitative standards \\
\hline 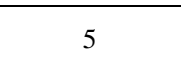 & $\begin{array}{l}\text { Law promulgated by the National People's Congress and } \\
\text { its Standing Committee }\end{array}$ \\
\hline 4 & $\begin{array}{l}\text { Regulations, directives and regulations promulgated by } \\
\text { the State Council; Orders of ministries and commissions }\end{array}$ \\
\hline 3 & $\begin{array}{c}\text { Provisional regulations and rules promulgated by the } \\
\text { State Council, standards of plans, decisions, opinions } \\
\text { and measures; The ministries promulgated the } \\
\text { regulations, rules and decisions }\end{array}$ \\
\hline 2 & $\begin{array}{c}\text { Opinions, methods, plans, guidelines, interim rules, rules } \\
\text { and standards promulgated by ministries and } \\
\text { commissions }\end{array}$ \\
\hline 1 & Notice, announcement, planning \\
\hline
\end{tabular}

Policy measures are the means used by the government to achieve its policy goals. Kim (1977) supposed that the government uses many direct and indirect measures to control the behavior of various companies in order to achieve the policy goals[10]. He divided the means into three types: means for strengthening demand, means for strengthening supply, means for adjusting the relationship between demand and supply. Li Rui believes that China's real estate inflow of foreign investment management policies based on multisectoral chain management mechanism, the transaction links around the "land use rights" set limits, exchange links to "Ministry of Commerce for the record" as the basis for enhancing management. Peng Jisheng divided our innovation policies into administrative measures, financial foreign exchange measures, fiscal and taxation measures, personnel measures and other economic measures. Xu Hongyi divided the policy measures of China's financial policies into monetary policy, interest rate policy and exchange rate policy. With reference to the above literature, and according to different policy measures on the degree of support for policy goals and implementation efforts, the FDI policy measures are divided into administrative measures, financial measures, financial measures, land policy measures. In order to facilitate the subsequent quantitative operation, we assigned values of 5, 4, 3, 2 and 1 for different standard of the policies. Table II shows the quantitative standard.

TABLE II. QUANTITATIVE STANDARD OF FDI POLICY MEASURES IN REAL ESTATE INDUSTRY

\begin{tabular}{ccc}
\hline $\begin{array}{c}\text { Policy } \\
\text { measures }\end{array}$ & Score & Quantitative standards \\
\hline $\begin{array}{c}\text { Administr- } \\
\text { ative } \\
\text { measures }\end{array}$ & 5 & $\begin{array}{c}\text { Relax administrative examination; simplify } \\
\text { examination and approval procedures, giving } \\
\text { priority to the principle of priority support. } \\
\text { formulate concrete assessment, supervision and } \\
\text { inspection measures for policies } \\
\text { Relax the administrative examination and } \\
\text { approval of support areas, to simplify part of the } \\
\text { approval process; mentioned the strengthening of } \\
\text { the implementation of the policies, did not explain } \\
\text { the inspection measures. }\end{array}$ \\
\hline
\end{tabular}

\section{Cont.to TABLE II}

Execute the administrative examination and approval strictly, complicated examination and approval procedures; the implementation of policies in general.

Strong support was given to financial lending and financial services, etc. set penalties clearly for enterprises disrupted the order; develop a monitoring method for the implementation of policies.

Financial measures

Give general support from financial credit policies and so on; strict financial loan order, strengthen credit supervision, but no specific regulatory measures.

Only mention the above methods. Give strong support in budget, subsidies, interest subsidies, etc. to give strong support in the tax, expressly proposed tax relief, quotas or support measures.
Give general support in budget, subsidies, interest

Fiscal and

taxation

measures subsidies, etc. proposed a certain amount of tax relief and support measures.

Just mention the above methods.

Give strong supports in the supply of land and compiles supply plans for that; lay down specific punitive measures for land use irregularities; give supervision methods for the implementation of land policies.

Land policy measures

Give general support in the supply of land; did not lay down specific punitive measures for land use irregularities.

Just mention the above methods.

The policy goals are the government's policy to achieve the purposes. After a detailed study of relevant policies from 2006 to 2015 and the current development of FDI in real estate industry, the policy objectives are divided into two dimensions: promoting industrial upgrading and stabilizing industrial development, and assigning 5 points, 3 points and 1 point respectively to different dimension. The specific quantitative criteria are in Table III.

TABLE III. REAL ESTATE INDUSTRY FDI POLICY GOAL QUANTITATIVE STANDARD

\begin{tabular}{|c|c|c|}
\hline Policy goals & Score & Quantitative Standard \\
\hline \multirow{3}{*}{$\begin{array}{l}\text { Promote } \\
\text { industrial } \\
\text { upgrading }\end{array}$} & 5 & $\begin{array}{l}\text { In order to optimize the investment structure of } \\
\text { FDI in the real estate industry, give strong support } \\
\text { from legislation, finance, administration and so } \\
\text { on; set forth standards of FDI. }\end{array}$ \\
\hline & 3 & $\begin{array}{l}\text { Formulated promotion plans in the key } \\
\text { investment fields; give support in finance and } \\
\text { taxation of promoting industrial upgrading; } \\
\text { conduct general reviews of the entry barriers to } \\
\text { FDI. }\end{array}$ \\
\hline & 1 & $\begin{array}{c}\text { Only related to the above terms, but there is no } \\
\text { policy measures. }\end{array}$ \\
\hline \multirow{3}{*}{$\begin{array}{c}\text { Stable } \\
\text { industrial } \\
\text { development }\end{array}$} & 5 & $\begin{array}{c}\text { Set plans of stable industrial development and a } \\
\text { local assessment of real estate FDI development } \\
\text { standards; strict implementation of the real estate } \\
\text { market order, develop rigorous management } \\
\text { measures. }\end{array}$ \\
\hline & 3 & $\begin{array}{l}\text { Formulated the implementation rules for the } \\
\text { development of the industry; stabilized the } \\
\text { development of the industry from aspects of } \\
\text { administration, finance, taxation, but the } \\
\text { implementation of measures was not strong. }\end{array}$ \\
\hline & 1 & $\begin{array}{l}\text { Only related to the above terms, but there is no } \\
\text { policy measures. }\end{array}$ \\
\hline
\end{tabular}




\section{Quantified Score Processing}

Quantified the scores of the policy potency, measures, goals, and then use $\mathrm{Xu}$ Hongyi measures of the financial policy formula, as shown in formula (1), the relevant policies for each year were accumulated to calculate the annual value of the policy indexes.

$$
R i=\sum_{j=1}^{N}(G 1 j+G 2 j)^{*} G 3 j \quad i \in[2006,2015]
$$

Where $\mathrm{i}$ denote the year, $\mathrm{N}$ denotes the number of promulgated policies, $\mathrm{j}$ denotes the $\mathrm{jth}$ policy promulgated in year i, G3j expresses the intensity of the jth policy, G1j and G2j denote the scores of the jth policy goal and policy measure respectively, and $\mathrm{Ri}$ denotes i-year comprehensive index of the indicators. The results are shown in Table IV.

TABLE IV. MEASUREMENT OF FDI POLICIES DIMENSIONS

\begin{tabular}{cccccc}
\hline years & $\begin{array}{c}\text { Policy } \\
\text { performance }\end{array}$ & $\begin{array}{c}\text { Policy } \\
\text { numbers }\end{array}$ & $\begin{array}{c}\text { Potency } \\
\text { score }\end{array}$ & $\begin{array}{c}\text { Goals } \\
\text { score }\end{array}$ & $\begin{array}{c}\text { Measures } \\
\text { score }\end{array}$ \\
\hline 2006 & 111 & 6 & 8 & 32 & 50 \\
2007 & 144 & 7 & 12 & 41 & 50 \\
2008 & 130 & 6 & 8 & 36 & 58 \\
2009 & 149 & 7 & 11 & 36 & 54 \\
2010 & 163 & 12 & 12 & 65 & 98 \\
2011 & 195 & 11 & 13 & 61 & 103 \\
2012 & 116 & 8 & 8 & 44 & 72 \\
2013 & 211 & 13 & 16 & 66 & 104 \\
2014 & 265 & 16 & 23 & 72 & 128 \\
2015 & 232 & 12 & 18 & 68 & 96 \\
\hline
\end{tabular}

\section{EMPIRICAL RESULTS ANALYSIS}

\section{A. Economic Indicators Selected}

Real Value of Real Estate FDI and Real Estate Industry Value Added in China Statistical Yearbook as Evaluation Index. The actual utilization of real estate FDI measures the effect of relevant policies on the introduction of foreign investment in the real estate industry. The added value of the real estate industry measures the extent to which the policies affect the industry as a whole. In order to eliminate the influence of the price factor, the nominal value of the above two indicators is defaulted with the GDP deflator to obtain the actual value of the indicators. The actual utilization amount of Real Value of Real Estate FDI and Real Estate Industry Value Added of the industry calculated according to 2006 constant prices are shown in Table $\mathrm{V}$.

TABLE V. THE ACTUAL VALUE OF THE TWO INDICATORS

\begin{tabular}{ccc}
\hline year & $\begin{array}{c}\text { Real Value of Real Estate } \\
\text { FDI(10 thousand dollars) }\end{array}$ & $\begin{array}{c}\text { Real Estate Industry Value } \\
\text { Added(100 million Yuan) }\end{array}$ \\
\hline 2006 & 822950.00 & 10370.50 \\
2007 & 1585152.96 & 12809.90 \\
2008 & 1599125.15 & 12678.37 \\
2009 & 1446740.34 & 16337.15 \\
2010 & 1931876.99 & 18983.98 \\
2011 & 2001969.89 & 20977.49 \\
2012 & 1754737.95 & 22728.65 \\
2013 & 2049054.01 & 25606.07 \\
2014 & 2443423.80 & 26815.62 \\
2015 & 2054912.61 & 29275.38 \\
\hline
\end{tabular}

\section{B. Related Analysis Between Quantitative Value and economic indicators}

Pearson correlation analysis of measurement indexes was carried out with different dimensions from SPSS 22, and the results are shown in Table VI. As can be seen from Table VI, except for the correlation between policy efforts and the added value of the industry at the 0.05 significance level, the measured values of other policy dimensions and the industry economic indicators are statistically significant at the 0.01 level. From the Pearson correlation point of view, the policy performance score and two industry economic indicators reached more than 0.8 , indicating that the real estate FDI policy is closely related to the introduction of FDI and the industry as a whole. The correlation coefficient between the scores of policy numbers, policy measures and policy goals and FDI actual utilization and the added value of the industry reached above 0.8 , indicating that the number of relevant policies, measures and targets are inseparable from the two economic indicators and may exist mutually Promote the relationship. The correlation coefficient between policy potency and economic indicators is relatively low, which shows to some extent that the influence of policy potency on the economic growth of the real estate industry is weak, but also shows significant statistics. In terms of the two economic indicators, the correlation between the actual amount of FDI and the five policy dimensions is relatively high, and all are statistically significant at the 0.01 level, indicating that the relevant policies have a stronger influence on FDI inflow to the real estate industry and the overall economy of the industry Changes in growth are relatively more affected by other factors. Table 6VIshows the results of the correlation analysis.

TABLE VI. CORRELATION COEFFICIENT

\begin{tabular}{ccc}
\hline $\begin{array}{c}\text { Policy } \\
\text { dimensions }\end{array}$ & $\begin{array}{c}\text { Real Value of Real } \\
\text { Estate FDI }\end{array}$ & $\begin{array}{c}\text { Real Estate Industry } \\
\text { Value Added }\end{array}$ \\
\hline $\begin{array}{c}\text { Policy } \\
\text { performance }\end{array}$ & $0.836^{* *}$ & $0.808^{* *}$ \\
Policy numbers & $0.875^{* *}$ & $0.834^{* *}$ \\
$\begin{array}{c}\text { Policy potency } \\
\text { score }\end{array}$ & $0.789^{* *}$ & $0.758^{*}$ \\
Policy goals & $0.885^{* *}$ & $0.829^{* *}$ \\
$\begin{array}{c}\text { score } \\
\text { Policy }\end{array}$ & $0.887^{* *}$ & $0.854^{* *}$ \\
\hline
\end{tabular}

\section{CONCLUSION AND SUGGESTION}

After analyzing the performance of FDI in China's real estate industry, we can see that the related policies can promote the healthy development of the real estate as a whole, and the policy performance is better. In terms of the dimensions for the measurement of policy, the three dimensions of policy goals, policy measures, and policy numbers have a significant impact on real estate FDI and the real estate industry, providing direction and effective methods for the development of the real estate industry. Measures to guide and supervise the real estate industry. In formulating policies, the government should maintain the current policy level in terms of quantity, focus on improving the quality of policies, clarifying goals and strengthening measures to make policy implementation more effective. Policy efforts in all factors, the real estate industry's FDI and real estate performance of the lowest, indicating that 
its impact on the development of the real estate industry is limited, the implementation of the policy implementation is still relatively weak, is not conducive to promoting the development of the industry. Therefore, in policy design, we must continue to step up our efforts in policies and introduce more effective policies to maintain the standardization of policies and the stability of the implementation of policies so as to meet the need of a smooth and healthy development of the real estate industry in our country.

\section{REFERENCES}

[1] S Malpezzi. Hedonic Pricing Models: A Selective and Applied Review[J]. Wisconsin-Madison CULER working papers, 2002, Vol.10,pp. 67-89.

[2] Lv Ying. Validity Analysis on the Policy of Limiting Foreign Capital Entering the Chinese Real Estate Market [J]. Jiangsu Business Theory,2007, Vol.12, pp. 8-9.(In Chinese)

[3] Li Rui. China's real estate foreign investment inflow management policy issues [J]. Financial Development Research,2011,Vol. 2, pp. 82-84. (In Chinese)
[4] Gary D. Libecap. Economic Variables and the Development of the Law: The Case of Western Mineral Rights[J]. The Journal of Economy History, 1978, Vol.2, pp. 338-362.

[5] Qian Wei, Lv Kewei, Systematic Study of Science and Technology Policy in Song Dynasty - Taking the Content of Science and Technology Recorded in the "Song History" as a Measuring Object [J]. Scientific research, 2007, Vol. 2, pp. 233-238. (In Chinese)

[6] Liu Chaofeng, Sun Yutao. Process Trends and Suggestions on the Evolution of China's S \& T Policy to Innovation Policy: An Empirical Analysis Based on 289 Innovation Policies in China [J]. China Soft Science, 2007, Vol.5, pp. 34-42. (In Chinese)

[7] Yin Huafang, Pan Zhen, Lu Minghong. China Foreign Direct Investment Industrial Policy Measurement and Effectiveness Research: 1979-2003 [J]. Manage the world,2006,Vol.7, pp. 34-45. (In Chinese)

[8] Xu Hongyi, Li sheng, Xu boron. Research on the Measurement and Effectiveness of China's Financial Industry Policy from 2001 to 2010 [J]. Wuhan Finance, 2014, Vol.1, pp. 25-28.(In Chinese)

[9] Peng Jisheng, Zhong for the country, Sun Wen detailed. Co-Evolution of Policy Measurement Policy and Economic Performance: An Empirical Study Based on Innovation Policy [J]. Manage the world, 2008,Vol.9, pp. 25-36. (In Chinese)

[10] Kim L. Imitation to Innovation: The Dynamics of Korea's Technological Learning[M]. MA: Harvard Business Press, 1977:11-34. (In Chinese) 